\title{
The Romantic Context of E. T. A. Hoffmann's Fairy Tales, The Golden Pot, The Strange Child and The Nutcracker and the Mouse King
}

\author{
Val Scullion ${ }^{1} \&$ Marion Treby ${ }^{2}$ \\ ${ }^{1}$ Independent scholar, Buckden, United Kingdom \\ ${ }^{2}$ Independent scholar, Newmarket, United Kingdom \\ Correspondence: Val Scullion, 51, Park Road, Buckden, St Neots, Cambs, PE19 5SL, United Kingdom. E-mail: \\ pjvj51@btinternet.com
}

\author{
Received: December 4, 2019 Accepted: April 13, 2020 Online Published: April 16, 2020 \\ doi:10.5539/ells.v10n2p40 URL: https://oi.org/10.5539/ells.v10n2p40
}

\begin{abstract}
As diaries, letters and the intensive intertextuality of his prose fiction show, the German Romantic writer and composer, E. T. A. Hoffmann (1776-1822), was an obsessive bibliophile and polymath. The aim of this article is to explore how far three of his literary fairy tales, The Golden Pot: A Modern Fairy Tale (1814), The Strange Child (1816) and The Nutcracker and the Mouse King (1816), use the generic conventions of the fairy tale, and how far they are influenced by his voracious reading, his encyclopaedic knowledge of literature, and his engagement with contemporary debates. We conclude with brief observations about his literary legacy in the genres of fairy tales and fantasy fiction.
\end{abstract}

Keywords: Hoffmann, fairy tale, fantasy fiction, imagination, legacy, romantic, oriental

\section{Introduction}

Significantly, Hoffmann's prose fiction was published between 1803 and 1822 . This places his work within the texts and debates of German Romanticism, which roughly spans the 1790s to the 1830s. His birth and death dates determine that he lived through a period of social turbulence and paradigm collapse in Europe, when, concomitantly, a massive exchange of ideas between artists, philosophers and scientists also took place. Romantic literary ideas focused in particular on the ascendancy of the imagination, and, at this time of ideological revolution, led to a re-evaluation of childhood and the child's innate and special gift of imagination. Hoffmann's letters and diaries record the practical difficulties of surviving throughout Napoleonic troop movements and French occupation of German states. This personal writing also indicates his professional triumphs and setbacks in such volatile circumstances. His numerous collections of tales, anecdotes, extended fairy tales and two novels (his two operas and countless musical pieces are beyond our scope here), testify to his participation in a concentration of literary activity. He acknowledges the contemporary influence of the Schlegel brothers, Novalis (Friedrich von Hardenberg), Wilhelm Wackenroder, Ludwig Tieck (Note 1) and many writers in translation, such as Cervantes, Shakespeare, Walter Scott, Laurence Sterne and Jonathan Swift (Note 2). This thumbnail sketch suggests the historical context of Hoffmann's writing and the mediating effects of the Zeitgeist. His literary fairy tales are a substantial part of his oeuvre and particularly represent his distinctive capacity to weave together the real and the fantastic in a seamless fictional whole.

\section{Generic and Contemporary Influences on The Golden Pot: A Modern Fairy Tale}

The shaping influence of an Oriental aesthetic was strong in German Romantic literature during Hoffmann's career as a writer. The stories of the Arabian Nights migrated to Europe by various literary and oral pathways, including via Antoine Galland's translation into French (1704-1706) (Warner, 2012, p. 12). Transmission of these tales to Germany, which was then a collection of states, principalities and districts, took place partially through J. H. Voss's translation of Galland into German (1781-1785), and then Christoph Martin Wieland's reworking of these tales in his Jinnistan, or Selected Fairy and Ghost Stories (1786-1787 and 1789) (Buch, 1992, p. 38). Hoffmann specifically refers to the Arabian Nights in his letter of 19th August, 1813 (Sahlin, 1977 , p. 203) and in his fairy tale, Little Zaches Acclaimed as Zinnober (1819) (Hoffmann, 1985, vol. 3, pp. 544-545) (Note 3). Furthermore, during this period, the Sanskrit scholar, philologist and Romantic philosopher, Friedrich 
Schlegel, published About the Language and Wisdom of the Indian which contains translations from the Bhagavad-Gita and other Indian mythologies (1808) (Willson, 1964, p. 219) (Note 4). There was also scholarly excitement at this time about the ground-breaking discovery in Egypt in 1799 of the Rosetta Stone, with its incised Egyptian hieroglyphics, Coptic script and ancient Greek. Wackenroder, as co-author of Tieck's Phantasus, also furnished Hoffmann with $A$ Wondrous Oriental Fairy Tale about a Naked Saint, who spins in the ether and eventually rises up into the heavens. Although later than Hoffmann's The Golden Pot, Goethe's cycle of exotic lyrical poems entitled West-eastern Divan (1819) is indicative of contemporary cultural interest in the East. This cycle was informed by the 1815 German translation of the Persian poet Hafiz by Joseph von Hammer-Purgstall (Warner, 2012, p. 309). Hoffmann also knew Wolfgang Amadeus Mozart's The Magic Flute, which, as a professional musician, he had both heard and conducted. Hoffmann was so inspired by Mozart's music that he even, in homage to him, changed his third name from Wilhelm to Amadeus. Like many fairy-tale operas of this period, the plot of The Magic Flute draws on an Oriental fairy tale from Wieland's collection, Jinnistan (Buch, 2004, pp. 206-208).

The first paragraph of The Golden Pot makes its Arabian heritage immediately obvious. It is a rewriting of a Persian creation myth which Hoffmann merges with the everyday life and naturalistic setting of Dresden. Its central character, the gauche, dreamy youth, Anselmus, arrives at full tilt, collides with the basket of an old apple-woman, and scatters its contents of apples and cakes. She demands the meagre contents of his wallet in recompense and croaks out an enigmatic curse on him that he will be confined in glass. Warner points out that "the plot of Aladdin, which upholds the rise of a worthless orphan boy to princely fame and fortune" and other hapless, lackadaisical youths in the Arabian Nights, have provided a pattern for fairy tales right up to the comic disasters of modern pantomime (Warner, 2012, pp. 17, 215). Hoffmann's variation of the plot entails Anselmus's earnest endeavours to make his way in life as a clerk and copyist of manuscripts, even though, as a visionary youth, he is clearly pulled emotionally in an opposite direction. Having no money for a beer to celebrate Ascension Day after the accident with the old apple-woman, he lies on the grass by the River Elbe bemoaning his ill-luck. As he looks up into an elder tree, he sees three glistening, tinkling little snakes, one with beautiful blue eyes (Hoffmann, vol. 2/1, p. 234). These otherworldly creatures, sisters and daughters to Archivist Lindhorst, give him a premonition that his life will transcend the daily grind and mundanity of the city of Dresden. He eventually marries the shape-shifting snake with blue eyes and lives with her in the enchanted land of Atlantis. Tormented by his vision, he still manages to keep his appointment to copy some manuscripts for Lindhorst, who is in charge of Dresden's precious archives and books and, simultaneously, is a salamander, "a lofty, majestic figure of the prince of spirits" (vol. 2/1, pp. 229-321). Lindhorst, as Bloch observes, "has a distinct oriental character" (Bloch, 1989, p. 272). Surrounded in his garden by fluttering, coloured birds, and dressed in a voluminous dressing gown covered in red and yellow flowers, he greets Anselmus, who is astounded to enter a house full of exotic wonders and luxurious plants that fill his senses with smell, sound and colour (vol. 2/1, p. 269) (Note 5). Lindhorst's house eventually becomes a portal through which Anselmus ascends to Atlantis and sees a lily in full bloom in the golden pot of the title. This is one of many examples of how Hoffmann weaves together real and fantastical worlds in the genre of the fairy tale. The quotidian life of Dresden society, his convincing depiction of petit bourgeois characters, together with recognizable locations in old Dresden are fused with equally well rendered magical elements. The credibility of its realist description can be judged by Zipes's reading of the fairy tale as a critique of the culture of Dresden in the first two decades of the nineteenth century: "a mundane society too immersed in pettiness and routine to appreciate the divine nature of life and art". He maintains that, by the closing chapters, Anselmus surmounts its endemic philistinism by entering the enchanted land of Atlantis, while the narrator also momentarily transcends the mundanity of his surroundings by completing The Golden Pot (Zipes, 2012, p. 115).

Anselmus's apprenticeship to Lindhorst entails him learning to copy Oriental manuscripts, which can only be done by achieving an expressive, almost trance-like state of mind. While endeavouring to learn the skill, his pen spurts an ink blot onto the precious parchment, a disaster that causes him to be stoppered in a glass bottle, as the apple-woman had foretold. Warner writes insightfully about the mystical power of calligraphy, particularly inscriptions on talismans, in the Arabian Nights. She argues that "word magic ... transforms raw matter into a symbolic object possessing power" causing "imagined outside forces" to be activated (Warner, 2012, p. 219). This makes sense of Anselmus's calligraphic and vocational struggle. Release from the bottle, a reworking of an Arabian jinn motif, marks his final flowering as a poet, and coincides with the narrator completing the task of writing The Golden Pot in a visionary, rather than in a mechanical, way (Hoffmann, vol. 2/1, p. 321). The power of calligraphy, script and lettering recurs in several of Hoffmann's tales. For example, Master Inky in The Strange Child imposes a grim régime of copying on his pupils - more of which below. In Little Zaches, Prosper Alpanus, a magus resembling Lindhorst and Shakespeare's Prospero, walks on curving hieroglyphics, which he 
calls the "worn-out talismans" of marble floors, and controls letters that jump out of his books (vol. 3, p. 608). Furthermore, in Kreisleriana (1814-1815), Hoffmann's accident-prone musical apprentice, Kreisler, complains that when writing a score, his notes jump off the stave, disfiguring the white paper like little black devils (vol. 2/1, p. 369). Oesterle focuses on the curving lines which feature strongly in The Golden Pot, for example in the architecture of Lindhorst's house, its luxurious plants and palms, the lettering on the ancient manuscripts, and the sinuous, shapeshifting forms of himself and his daughter, Serpentina, the snake with the blue eyes. He (Oesterle) concludes, after lengthy argument, that Hoffmann's The Golden Pot produces "multi-referential forms of script (multireferentielle Textform) (Oesterle, 1991, pp. 106-107). These not only display the influence of what Warner calls the "word magic" of the Arabian Nights (Warner, 2012, p. 219), but also echo the contemporary academic study of philology, linguistics, hieroglyphs, and the ancient Indic language, Sanskrit (Willson, 1964, pp. 199-201).

There is probably a contemporary cultural hinterland, as well as an Oriental literary influence, behind Hoffmann's emphasis on handwriting in The Golden Pot. Kittler refers to Hoffmann's description of Anselmus as "thunderstruck" when he sees with new eyes the scrawl of his old alphabetical copying style, and his slow graduation to "inscribing the parchment with long-familiar characters, and scarcely need [ing] to glance at the original" (Hoffmann, vol. 2/1, pp. 273, 284). He (Kittler) analyses in great detail the recurring theme of handwriting and the mastering of serpentine lines in The Golden Pot, placing it within the context of contemporary pedagogical reform in writing and literacy (Kittler, 1990, pp. 77-108). An abundance of reading and writing primers published from the 1790's onwards testifies to a rapid shift in ideas about literacy (ibid, p. 27). One paradigmatic example suffices, that of Heinrich Stephani, whose primer replaced rote-learning of letter names with a new phonetic method, and advocated an understanding of the meaning of words and listening to the mother's reading voice (ibid, pp. 28, 33). We would add that Anselmus's acquisition of a new handwriting practice is concomitant with his surrender to a belief in a magical realm. Hoffmann's preoccupation with handwritten script and his self-consciousness about his own "small and crowded", "microscopic" and "flea-footed" writing seem to lie as a palimpsest behind this contemporary issue (Note 6).

Anselmus's eventual ascendance to the kingdom of Atlantis is also notably shaped by Hoffmann's love of G. H. Schubert's work. He describes Schubert's Opinions on the Nocturnal Side of Natural Science (1808) as a "magnificent book" and Schubert as a "brilliant man" (ibid, p. 203). According to his scientific theories, the universe comprises three epochs: the first when all human beings were in tune with nature; a second when they lose spiritual harmony and use of original language; and a third when artists and visionaries become capable of reconnecting with the lost primal world, though philistines may never cross the boundary (Note 7). The Golden Pot can be read as an allegory of these theories as Anselmus journeys towards the lost primal world of an ancient Persian paradise. Here palm trees rustle softly "like tones of melodious harps"; dazzling beams of light shoot through perfumed vapours; shining insects dance in the air and birds sing. In a similar way to Heinrich von Ofterdingen's inspiring encounter with the blue flower in his vocational dream (Novalis, 1990, p. 17), flowers also greet the budding poet, Anselmus, on his arrival. Serpentina then presents him with a lily in the golden pot of the title, which he perceives to be "knowledge of the sacred harmony of all beings ... which sprang from the primeval force of the world" (Hoffmann, vol. 2/1, p. 320).

Lastly, as Bloch argues, The Golden Pot follows in the footsteps of all good art, especially fairy tales, by fulfilling a utopian function. He observes that "in great art, exaggeration as well as telling stories are most visibly applied to tendentious consequences and concrete utopia." Hoped-for possibilities might or might not materialize exactly as dreamed or daydreamed, but they "mediate a presentiment of future freedom" by offering an "aesthetic anticipatory illusion" (the last phrase being a translation of Vor-schein) (Zipes \& Mecklenburg, 1989 , p. 148). Fairy tales, therefore, offer hope to listeners and readers through castles in the air and happy endings, which wishful thinkers and dreamers often attain (ibid, p. 178). Hope is such a consistent fairy-tale trope, that if a fairy tale lacks this generic fulfilment, then it is still subject to an interpretation as a satiric or ironic revision of genre expectations. Hope, even if qualified, concludes all of Hoffmann's literary fairy tales. Anselmus's day-dreaming and imaginative thinking certainly propel him to a "loftier existence" in Atlantis, while the narrator of The Golden Pot, on its completion after a period of writer's block, is raised up to an understanding of the inner power of his own imagination (Hoffmann, vol. 2/1, p. 321). Similarly, the commedia dell'arte actors, Giacinta and Giglio, in Hoffmann's fairy tale, Princess Brambilla (1820), visit the magic realm of Urdurland and both achieve selfknowledge in their eventual marriage in the real world (vol. 3, p. 910). And, in step with these utopic endings, the dreamy young poet, Balthasar, in Little Zaches, yearns for a better life and achieves it in a fairy-tale wedding to his beloved Candida. Immediately after the wedding, Prosper Alpernus is transported up into the clouds through blazing rainbows in a magical carriage drawn by silver pheasants and 
shimmering dragonflies (vol. 3, p. 648).

\section{Generic and Contemporary Influences on The Strange Child}

Published in 1816, Hoffmann's literary fairy tale, The Strange Child, is typically German Romantic, mediating the literary and cultural Zeitgeist. Its structure is shaped by contemporary Romantic and Oriental literary devices and underpinned by Hoffmann's engagement with contemporary aesthetic theory. In all of his literary fairy tales, Hoffmann uses a convoluted form of storytelling. This claim is self-evident if they are compared with Jacob and Wilhelm Grimm's contemporaneous fairy tales which are, by contrast, short, and tend towards a literary imitation of oral storytelling (Note 8). Hoffmann's The Golden Pot eschews narrative linearity by using plots, characters and settings incorporated into digressions. Both The Strange Child and The Nutcracker use the device of a story within a story, which disrupts the narrative flow. These narrative techniques align with Schlegel's Romantic aesthetic maxims, which describe them as arabesques (Arabeske). They constitute "artistically ordered entanglement (künstlich geordnete Verwirrung) and random connectedness of form (zufällig Verknüpfung von Form) (Note 9). Schlegel also asserts that the "most important thing in the novel is chaotic form-arabesque, fairy tales" (Note 10). In short, arabesques subvert obvious connectives between one section and another. At the same time, as argued above, Hoffmann's fairy tales also bear the literary imprint of recent translation and reworkings of the Arabian Nights, the structure of which is dictated by Scheherazade's convoluted stories that roll along from night to night, making frequent use of narrative embedding in order to postpone endings and to ensure her survival. As Warner succinctly argues, the word arabesque, originating from Moorish decoration in Spain, describes both artistic or narrative frames and intricate ornamentation. It involves "a pattern efflorescing on all sides" which is "endlessly generative and cyclical", resulting in "the nested boxes and self-mirroring regression of the Nights" (Warner, 2012, pp. 7, 11). The influences of Romanticism and Orientalism thus converge.

As part of the developing discourse of Romanticism at the beginning of the nineteenth century, a trope of aerial lightness and suspension was often used as one of many ways to describe the imagination, the faculty it valued above all others. Schlegel's maxims verify and substantiate this. He urges writers and artists to "hover in the middle (in der Mitten schweben) on the wings of poetic reflection" (Note 11) in order to maintain a state of creative balance between spirit and matter. One of his maxims states that the true Romantic artist is suspended between two spheres of chaos and order; this is a state of temporary level-headedness or equilibrium which he calls Bessonenheit (Note 12). Hoffmann was ever receptive to and well informed about contemporary aesthetic debate. In The Serapion Brothers (1819-1821), for example, Brother Theodor, one of the main contributors to aesthetic dialogue, describes poetic inspiration as follows:

I think that the bottom of the ladder to heaven on which one wants to climb up into higher regions must be grounded in life ... If, having climbed higher and higher, he [the writer or artist] then finds himself within a fantastic magical realm, he will come to believe that this realm too is part of his life, and that this realm is actually the most wonderful part of it. (vol. 4, p. 721)

Theodor argues that fairy tales which follow the Oriental pattern of Scheherazade's storytelling are too rarefied to achieve this, but Brother Ottmar strongly disagrees. He argues that many a reader or listener occupied with ordinary work and daily business would become dizzy even if perched on the third rung of the literary ladder. However, he maintains, the power of the Arabian Nights is so strong that the most wonderful magic shoots into the middle of everyday things (mitten in der Alltäglichkeit), and suspension of disbelief transforms the world around us (vol. 4, pp. 720-721). In other words, a bit of magic is not exclusive to poets and artists higher up the ladder. This fundamentally Schlegelian concept of elevation gives Hoffmann the scope to critique its nuances and to develop his own characteristically quirky version, so expertly conveyed in The Strange Child.

The trope of the aerial overview was, therefore, part of the contemporary melting pot of Romantic discourse, and one of many literary devices mediated through the Arabian Nights. As Warner argues, "In the Nights, flying gives one of the most characteristic fantasy experiences ... Flight happens without any to-do; it is a dynamic of the plot ... and the key image in oneiric storytelling" (Warner, 2012, p. 331). In these Oriental tales, jinns, giant birds, enchanted horses and carpets carry off their human cargo into magic realms of the imagination, opening up "a vista of metaphorical meanings for the human subject" (ibid.). The literary context of the Arabian Nights was fertile ground for Hoffmann and his fellow writers in which to create variations, and the magic of flying gives both energy and charm to The Strange Child. His own pen and ink drawing depict the Strange Child from below and behind, as a feminine, angel-like figure flying home holding a rose (Hoffmann, vol. 4, p. 1200, No. 7). This mysterious child makes the brook babble and the birds sing so that brother and sister, Felix and Christlieb, are inspired to build castles from pebbles and imagine their own sparkling castles in the air. Zipes compares the 
Strange Child to the alien E. T. in Spielberg's 1982 film "who comes from space to help young children to learn to empathize and tolerate strangers in their lives" (Zipes, 2007, p. 25). The ability to fly reappears in children's fantasy literature again and again, for example the light Princess, cursed at her christening with no gravity; Alice skimming across the chessboard with the Red Queen; Peter Pan and friends on their way to Neverland; and Mary Poppins flying with the aid of her umbrella (Note 13).

The flying trope in The Strange Child is also influenced by the contemporary novel, Heinrich von Ofterdingen (1802) by Novalis (Note 14). Critical attention is usually given to the opening of the novel which comprises Heinrich's dream of a blue flower. Like Anselmus in The Golden Pot, he yearns to become a poet and the flower symbolizes his future vocation. However, a second dream immediately follows, described by Heinrich's father, in which a small, shining child takes him and his wife into its arms and soars with them into the clouds (Novalis, 1990, pp. 22-23). This event is replicated in Hoffmann's literary fairy tale when the mystical Strange Child makes its first appearance, heralded by an otherworldly "radiance" and "wonderful musical notes" (Hoffmann, vol. 4, p. 585). It takes Felix and Christlieb by the hand up into "airy flight" (vol. 4, p. 587). Hovering in the sky, they can see a castle made of jewels in the clouds, the home of the Child's mother, the Queen of the Fairies. As Kittler argues, "a stranger [the Strange Child] ... teaches earthly children by means of poetry to escape the alphabetical method of their writing master" (Kittler, 1990, p. 81). Flying certainly allows them to escape the stultifying rote-learning of the classroom administered to them by their cruel tutor, Master Inky (Magister Tinte). Their flight is also a fine example of access to what Tolkien describes as "Faërie, the realm or state in which fairies have their being" (Tolkien, 1966, pp. 9-10).

Learning to fly also gives free rein to the imagination. Felix and Christlieb particularly excel at creating stories based on their individual experiences of the material world. For example, the Child appears to Felix to be a boy and to Christlieb to be a girl. Kümmerling-Meibauer places this fairy tale's emphasis on androgyny firmly in the Romantic tradition, comparing the Strange Child to Mignon in Goethe's Wilhelm Meister's Apprenticeship (1795-1796) and to Charles Lamb's visionary Dream-Children in his collection The Essays of Elia (1823) (Images unpaginated). Mignon is an artistic youth who follows Wilhelm, but dies young before growing into a firmly gendered identity, while the Dream-Children wait on the edge of consciousness for an existence and a name for millions of years. She concludes that the defining features of a Romantic child are "creativity, vitality, imagination, contemplation ... experience of nature and contact with the divine" (Kümmerling-Meibauer, 2008, p. 187). The setting of The Strange Child is also thoroughly Romantic. Felix and Christlieb's parents, Sir Thaddeus and Lady von Brakel, live in a rustic dwelling surrounded by woods, flowers and bird song. Although financially straightened, they give them an abundance of books to read and the freedom to wander. Zipes points out that Hoffmann read Rousseau's Emile; Or On Education (1762) as a young man, which may have influenced his depiction of children happily rambling in the countryside (Zipes, 2007, pp. 24-25). As Rousseau advocates, when "fresh air ... enters every pore of a soft and tender skin, it has a powerful effect on their young bodies" (Rousseau, 2007, p. 35). It is in the woods that the Strange Child enhances the children's intuitive understanding, a sensitivity to nature and a feeling of transcendence through flying (Hoffmann, vol. 4, p. 591).

The Strange Child is clearly focused on how the glorious imagination of children can be preserved as they grow up. This echoes the radical child-rearing philosophy illustrated in Novalis's Heinrich von Ofterdingen where Heinrich's parents are unusual in raising him without "the slightest parental hampering", in the belief that a child has "the stamp of a marvellous world which no earthly flood has yet made unrecognizable" (Novalis, 1990, pp. 160-161). The noble, but impoverished, von Brakels tend in the direction of Heinrich's parents with regard to their instinctively progressive attitude towards their son and daughter. Probably unconsciously, they put into practice many of the values that are closely bound up with Romanticism. The von Brakels are literally country cousins to Count Cyprianus von Brakel, whose visit makes them aware of a more conventional way of educating children. Count Cyprianus, as an important, wealthy courtier, offers to pay for a tutor, the aforementioned Master Inky, to take charge of Felix and Christlieb's learning. By agreeing to this plan, the parents unwittingly precipitate the loss of their idyllic childhood. Herrmann and Adelgunde von Brakel, in comparison with their country cousins, are "hothouse" children, impeccably and expensively dressed, frightened of the family dog, and of Felix and Christlieb's rumbustious behaviour. Felix and Christlieb are equally baffled by their cousins' ability to reel off, like performing parrots, many scientific and geographical facts and figures which they do not understand. They bring expensive toys for their cousins to play with, but Christlieb's wax doll and Felix's mechanical shooter and musical box do not survive a good romp in the woods, the doll being flung in a pond and the broken shooter and musical box into the bushes. The visit ends with Herrmann and the two girls crying, and Felix angry with the boy, whom he disparagingly calls "silly knickerbockers" (Hoffmann, vol. 4, p. 579). The two sets of cousins illustrate how the imagination of children can be encouraged or quashed. The Strange Child, 
therefore, critiques the parental style of Count Cyprianus and his wife, who love and indulge their children, but stunt the development. It ridicules repressive fact-crammed learning and gives a positive bias to fostering children's innate creative capacities.

The structural comparison of the two sets of cousins is replicated in the polarization of the Strange Child and the grotesque Master Inky. His educational methods undermine Felix and Christlieb's special perception of nature and their easy access to the enchanted world of fairies, which was once instinctive and visionary. He first greets Felix and Christlieb by pricking their hands with a spiked handshake, and he makes their lives a misery by confining them to the classroom. The von Brakel parents have serious second thoughts about him, and insist that their children be allowed to run in the open air. Pursuing them, their tutor destroys the enchantment of the woods by killing a bird with a stone and uprooting wild flowers (vol. 4, p. 603). The brother and sister are then haunted by their discarded toys which, on Master Inky's orders, metamorphose into terrorizing automata (vol. 4, p. 610). Lady von Brakel is disgusted by his repulsive manners and his habit of shoving his nose into the sugar box (vol. 4, p. 606). Persuaded by the children, and then by the evidence of their own eyes, the parents come to see that Master Inky is not human. The family watch him degenerate into a house-fly, which they swat and drive away. However, his punishment comes only after he has tainted Felix and Christlieb's childhood paradise in the woods. In Hoffmann's drawing, Master Inky is a composite figure of human and fly-like appearance, who drives the Strange Child off into the sky and menaces the siblings with his quill pen (vol. 4, p. 1200, No. 7).

The relationship between adults and children features strongly in this fairy tale. According to contemporary received wisdom, adults were the sole custodians of knowledge and knew what was best for children. The plot challenges this common adult-child power relationship. This theme is also prevalent in The Elves (1812), from the fairy-tale collection Phantasus by Ludwig Tieck, which Hoffmann describes as "magnificent" (Sahlin, 1977, p. 300). Here, the mother of a young child who is in touch with fairies, describes her own childhood relationship with them. Her adult re-encounter with the fairies drives them out of the material world (Tieck, 1812, unpaginated). In similar vein, Sir Thaddeus von Brakel initially remonstrates with his children, asking "Whoever put all this nonsense in your head?" (Hoffmann, vol. 4, p. 606), but like the mother in The Elves, both parents listen to their children's experiences and come to believe in the presence of fairies. The von Brakels become childlike adults who share with their children a belief in Romantic ideals, especially in difficult circumstances. During his last hours, Sir Thaddeus remembers very well that as a small boy he too was visited by the Strange Child and bids Felix and Christlieb to "keep (the child) firmly in your minds" (vol. 4, p. 613). After their father's death, the children's imagination enables them to empathize in a mature way with their widowed mother. Despite their poverty, the children grow into happy, successful adults, helped by the Strange Child's oneiric presence. Hoffmann's tale, therefore, offers more hope than Tieck's The Elves. The Strange Child is a strong endorsement of the developing capacities of Romantic children and celebrates their ability to mediate their transcendent experiences to receptive adults, to rekindle their connection with the imagination and dreaming, and, on a practical level, to alleviate their suffering.

The embedded story within The Strange Child echoes the conflict between the Strange Child and Master Inky which is narrated in the outer framing narrative. In the story within the story, Master Inky metamorphoses into Pepser, King of the Gnomes, who is a constant threat to the Strange Child and its homeland. In the annals of the fairy realm, Pepser and his hordes of flies had once defiled it with disgusting black fluid. He pulled little fairies out of trees and caused their noses to bleed by forcing them to crawl on all fours. Hoffmann's history of fairyland celebrates the bravery of little fairies who, armed with fly-swatters, repulse the invaders and restore their world to a place where they can "romp and play, shouting for joy" (vol. 4, p. 595). The battle of the Strange Child and Felix and Christlieb against Master Inky is, therefore, told twice over, the inner story focusing on fairy children against the tutor's alias, King Pepser, and his hordes of flies. This arabesque device of embedding doubly emphasizes the agency of children. Thus, the two narratives in The Strange Child work in tandem; the one, set in the realist world of the von Brakels, is consolatory, and the other, set in the Strange Child's fairyland, is utopic. The two worlds coalesce in Felix and Christlieb, the paradigmatic Romantic child-protagonists who are conduits to carry their parents to the imaginary realm. The inner story brings hope to Felix and Christlieb that a fairyland can be reinstated and that children can make their own real world a better place. This hope is stronger than an escapist fantasy - a feature of the fairy-tale genre observed by Bloch, in his description of "anticipatory illumination" and wishful dreaming (Bloch, 1988, p. 22). The Strange Child celebrates the imaginative perceptions, resourcefulness and exuberance of Hoffmann's child-characters by showing that they can succeed in tasks that are usually considered to be the responsibility of adults.

\section{Generic and Contemporary Influences on The Nutcracker and the Mouse King}

Also published in 1816, Hoffmann's literary fairy tale The Nutcracker and the Mouse King is another example of 
German Romanticism, enriched by Hoffmann's self-reflective Schlegelian irony, which permits multiple interpretations of events and ideas. The positioning of the narrator in The Nutcracker at the intersection of the fantastic and the real world reflects the creative process itself, and, like The Strange Child, it too celebrates the power of the imagination so valued by the Romantics. In the frame narrative of The Serapion Brothers, the Brothers discuss whether these two fairy-tales are suitable for children (Hoffmann, vol. 4, pp. 306-309, 615-616). Brown states that, because they are both positioned as the last story in a volume, they "ensure that there will be a balancing out, that any dissonances [between the Brothers and between the tales] will be resolved and that the mood on parting will always be brought back to a happy state of equilibrium" (Brown, 2006, p. 10). In The Nutcracker, Hoffmann's narrator focalizes sympathetically through the experiences of the young protagonist, six-year-old Marie Stahlbaum. In keeping with Brother Theodor's statement in the aesthetic discussion on poetic inspiration that "the bottom of the ladder to heaven on which one wants to climb up into higher regions must be grounded in life" (Hoffmann, vol. 4, p. 721), The Nutcracker grounds the fantastic within an authentic, middle-class, family setting at the beginning of the nineteenth century. Yet, at the same time, it features a truly credible heroine, Marie, who is "satisfied only when she can experience another, fantastic world" (O'Sullivan, 2005, p. 26). Hoffmann anchors many of this fairy tale's magical events so effectively in reality that the reader initially suspends disbelief and is persuaded of their veracity. Nikolajeva aptly uses this term "anchoring" to identify "the presence of magic, or any other form of the supernatural, in an otherwise realistic, recognisable world" (Nikolajeva, 2003, p. 141). It is on closer reading that equivocation emerges. The close of the tale, when the narrator assures the reader that Marie marries her Nutcracker-Prince, is particularly equivocatory in terms of merging the real and the fantastic. The marriage can be read simultaneously as a fairy-tale happy ending in the fantastical world, and as a yet unfulfilled hope, to use Bloch's phrase, in the real world. The narrator's empathy with Marie leads him to paint such a convincing picture of the Nutcracker-Prince as an apprentice from Nuremberg, that the reader is encouraged to give credibility to both worlds, making no distinction between them. Yet, in the real world, Marie's parents and the family physician, Doctor Wendelstern, clearly think that her imaginings can be accounted for by her injury, namely that she has cut herself by falling on her glass-fronted toy cupboard and has lost a lot of blood. It is Hoffmann's multi-faceted presentation of the imagination which leads O'Sullivan to argue strongly that this literary fairy tale is not only "pioneering" but that it gives Hoffmann the status of "founding father of children's fantasy" (O'Sullivan, 2005, p. 26). Significantly, Nikolajeva also acknowledges that The Nutcracker is a "pioneering work" (Nikolajeva, 2003, p. 139).

According to Kümmerling-Meibauer, the Romantic child is an imaginative being with many perceptions superior to those of adults whose senses have become less acute with maturation (Kümmerling-Meibauer, 2008, pp. 192-193). She argues that the Romantic child is often a "mediator" to a world that adults have left behind (ibid, p. 187). Spontaneous, intuitive and creative, Romantic children are constructed as rather isolated and misunderstood because of their special perceptions of transcendent, poetic, divine or magical worlds. They are, therefore, the very opposite of the Enlightenment idea of the child as an adult-in-waiting (ibid, p. 188). Hoffmann's characterization of Marie broadly conforms to contemporary ideas, thereby suggesting a radically different view of the child from the received eighteenth-century wisdom, which Carpenter succinctly expresses as follows:

To the typical writer of the Enlightenment, a child was simply a miniature adult, a chrysalis from which a fully rational and moral being would duly emerge, providing parents and educators did their job properly. There was no question of children having an independent imaginative life of any importance, or of their being able to perceive anything that was invisible to adults. (Carpenter, 1985, p. 7)

Like Felix and Christlieb in The Strange Child, Marie epitomizes a Romantic child with a vibrant imagination. An independent thinker, she is tenacious about her own perceptions, despite the disapproval of her brother Fritz, her parents and Doctor Wendelstern in the real world. They dismiss Marie as a little dreamer, whereas The Nutcracker as a whole celebrates her special gifts. Marie's supernatural experiences begin somewhat differently from those of Felix and Christlieb. She too forms a close relationship with a sentient being, but, in contrast to the ethereal Strange Child, Marie's guide is a much more mundane object - a wooden nutcracker given to her as a Christmas present. However, it is significant that, according to German tradition, nutcrackers bring good luck and good fortune to the home. With the help of Marie's imagination, the nutcracker undergoes an initial transformation into life, and a second, more radical transformation when it becomes a handsome prince and Marie's bridegroom. This follows the generic trope of transformation which recurs in simpler folk forms of the fairy tale. Hoffmann also uses this transformational trope in The Strange Child when Master Inky metamorphoses into a housefly, and then into Pepser. Serpentina, in The Golden Pot, also shape-shifts from a snake to a voluptuous young woman, whom the callow Anselmus initially encounters with embarrassment. 
Marie's imaginative sensibilities find companionship and empathy with the nutcracker, both as the doll and as the Nutcracker-Prince which he becomes in the magic Kingdom of Toyland. Like most traditional fairy tales, The Nutcracker closes with a fairy-tale wedding. Here, Marie marries her Prince, and is transfigured from a little girl into the Queen of a magical country. According to the narrator, she remains its Queen to this day, thus becoming a generic character in her own fairy tale. The narrator concludes The Nutcracker with the observation that the imaginary world is open to "those who have eyes to see it" (Hoffmann, vol. 4, p. 306). By "those" he refers generally, not just to Marie, but to all child-readers and listeners to the tale, and to any childlike adults who suspend their disbelief and surrender to their imagination. The prominence of the narrator's announcement precludes an interpretation of Marie's adventures as merely feverish and delusionary.

Kümmerling-Meibauer suggests that, in "taking the child's inner life seriously", Hoffmann is developing a new literary poetics of the uncanny (Kümmerling-Meibauer, 2008, p. 192). Uncanny, in this context, refers to the eruption of fantastical tropes into the description of a child's everyday family life, a literary version of Freud's merging of the "heimlich" and "unheimlich" (Note 15). Marie's imaginative experiences begin within her own home, when familiar objects, such as her toys and the owl on the nursery clock, come alive in an uncanny way. The world she has imagined is both detailed and substantial, a place where she is not a spectator, but a participant. Significantly, she bribes the Mouse King with her Christmas sugared sweets to prevent him biting off the nutcracker's head and throws her shoe at the Mouse King (Hoffmann, vol. 4, p. 261). This is spirited behaviour for a middle-class German girl-child in the early nineteenth century. As if to thank her for her actions in saving him, the Nutcracker-Prince escorts her to the magic Kingdom of Toyland, assuring her that her imagination has created it. Here, her senses are assailed by an enchanted land, beautiful countryside, bustling cities, wonderful confections and unusual sights and sounds. Typically in Hoffmann's fairy tales, Oriental tropes play their part. In addition to six monkeys playing Turkish military music at the first city gate through which Marie passes with her Nutcracker-Prince, Hoffmann depicts the Sultan of Turkey's procession through the capital city, with a marching band of three thousand Janissaries whose "tumultuousness and high-pitched, shrill sounds" contribute to the exotic, sensory nature of Marie's imaginary realm (Neilly, 2016, p. 100). Everything is the antithesis of her family home, and offers her all the joy of what Tolkien calls a "Secondary World" (Tolkien, 2008, p. 52).

Marie quickly realizes that her parents, her older brother and Doctor Wendelstern will reject her account of her adventures. When she awakes from the pleasant visions of the Kingdom of Toyland, her mother's attitude echoes that of the father in Novalis's Heinrich von Ofterdingen, who initially tells his son: "Dreams are spindrift ... and you will do well to turn your mind away from such useless and harmful reflections" (Novalis, 1990, p. 18). His temporarily dismissive attitude to his son's dreams echoes that of the von Brakels when they first hear about the Strange Child. However, they all quickly learn to take the otherworldly experiences of their offspring seriously, whereas Marie's parents are impervious to anything irrational, and her brother also adopts this attitude. Even the presence of a talisman which she brings back from Toyland, the seven crowns which the dead Mouse King had once worn, does not sway Marie's father, although her mother seems to experience a fleeting moment of doubt. Marie is perplexed when Drosselmeier also sides with her parents in denying that she has visited a magical place (Hoffmann, vol. 4, p. 303). In the family's presence, he undermines the proof of the seven crowns, when he claims that they are just decorations he has worn on his watch chain. Then Marie becomes "quiet and meditative, absorbed within herself" and begins to understand that her Godfather only partially experiences the enchanted realm where his transformed nephew is trapped (vol. 4, p. 304). Further evidence that Drosselmeier's imaginative powers are less than a child's is evident in the Nutcracker-Prince's comment that his uncle could not have created the Kingdom of Toyland - it was Marie who did so. This enigmatic handling of the evidence of the talisman by Hoffmann's narrator is further testament to the skill with which Hoffmann conflates real and fantastical worlds.

Marie intuits correctly that, because her Godfather Drosselmeier builds a mechanical castle containing automata; chants strange rhymes; mends clocks; makes mousetraps and repairs the nutcracker's mechanism, he has a degree of empathy with the world of her imagination. Having listened to his story of "The Hard Nut", in which Princess Pirlipat refuses to rescue a cursed prince, Marie works out the connections between this fairy-tale princess and herself. She believes that her Godfather knows the wooden nutcracker is his nephew, and that he wants her to break the curse put on his nephew by the Rat Queen. The embedded fairy tale is, therefore, a test of Marie's imaginative powers. This arabesque device attributes agency to Marie in both the inner and the outer stories. Zipes insightfully calls the inner tale "antitraditional" because it is "macabre", "unsettling" and lacks a happy ending (Zipes, 2007, p. 23), an interpretation which aligns with Kümmerling-Meibauer's comment that Hoffmann develops a new literary poetics of the uncanny. When Marie asks Drosselmeier why he cannot restore 
his nephew to human form himself, his reply shows his thorough understanding of the imaginative powers of a child. He explains, "More is given to you, Marie dear, than to me, or others. You are a born princess, like Pirlipat, and reign in a bright beautiful country. But I cannot help him; you and you alone can do that" (Hoffmann, vol. 4, p. 284). This also concurs with Kümmerling-Meibauer's analysis that the imagination decreases as one becomes adult (Kümmerling-Meibauer, 2008, pp. 192-193).

The rigid régime of child-rearing through rote-learning and drill, so ridiculed in The Strange Child, is less well developed as a theme in The Nutcracker, but the same conventional attitudes to childhood pertain. Adults in The Nutcracker condemn Marie's story as the product of a feverish mind and body. Doctor Wendelstern even suggests that Drosselmeier's weird and wonderful demeanour could be cured by medicine. Like Drosselmeier, Anselmus in The Golden Pot also retains his creative imagination beyond his youth, and so joins Hoffmann's gallery of artists, poets and magi who transcend the limitations of ordinary adulthood and the entrapments of a petty bourgeois society. As Zipes points out, Marie's family surname is Stahlbaum, which means steel tree. He argues that the name encapsulates the family's lack of affinity with anything transcendent or visionary. It suggests a non-naturalistic phenomenon, a cold, rigid framework of reference, or a reductive, distorted form of Enlightenment thinking (Zipes, 2007, p. 21). Although the adults and Fritz reject Marie's Romantic perspective, it is reinforced by the development of the plot, especially when she saves the Nutcracker-Prince's life in the magic realm. Furthermore, Zipes suggests that Hoffmann's ending, when Marie marries Drosselmeier's nephew from Nuremberg, "reconciles the real and imaginative realms", thereby confirming Hoffmann's validation of the power of the imagination (Zipes, 2007, p. 23).

Fritz, the philistine brother, manifests a darker, negative side of the Romantic child, described by Kümmerling-Meibauer as exhibiting "savagery and self-regard" (Kümmerling-Meibauer, 2008, p. 187). His creativity leads him into mischief, bullying and destruction. He is interested in war-games, and handles the wooden nutcracker roughly, breaking its mechanism for cracking nuts with its teeth. His imaginative engagement with his army of toy soldiers and his later mockery of his little sister's adventures show him to be on the cusp of outgrowing his childhood. He keeps his soldiers and their equipment in "military quarters" in the toy cupboard with the nutcracker and Marie's dolls, and has a detailed knowledge of hussars, dragoons and cuirassiers. He plays out military battles with them and invests these with such ferocity that Marie protests "You're a hard-hearted creature! You beat your horses, and you have had one of your soldiers shot", which he justifies as military discipline (Hoffmann, vol. 4, p. 249). He is so absorbed in these games that he even gives a sword that he has taken from one of his retired generals to Marie, so that her Nutcracker-Prince can fight the Mouse King. However, as The Nutcracker progresses, Fritz becomes a crass youth and agrees with his parents that Marie's adventures are merely make-believe. It is telling that the several pages devoted to a description of the battle between the allied forces of Nutcracker-Prince's toys and Fritz's soldiers against the hordes of mice in the Mouse King's army, are focalized through Marie, thus implying her possession of a greater creativity than her brother. The battle scene is remarkably realistic, beginning with an explosion of "sand and lime and broken stone" bursting at her feet as the seven-headed Mouse King rises out of the floor (vol. 4, p. 255). The troop manoeuvres during the battle are authentic strategies in a theatre of war, and surely owe something to Hoffmann witnessing the bloodshed of warfare and seeing civilians caught in crossfire in Leipzig and Dresden in 1813 (Note 16).

Hoffmann's The Nutcracker is his most famous work, partially owing to its many offspring in media forms, ballet and film, and it is probably his most original. He was one of the earliest fairy-tale writers to use the trope of a portal, a device which involves crossing a liminal space to reach another world. Marie can negotiate portals with ease. When the Nutcracker-Prince invites her to follow him into the Kingdom of Toyland, she enters by climbing a cedarwood staircase within the sleeve of a fur coat hanging in a wardrobe. Once in the kingdom, with the Nutcracker-Prince's help, she also moves swiftly and effortlessly from one magical location to another, including skimming over water in a beautiful boat (vol. 4, p. 295). As her time in Toyland comes to an end, she rises "higher and higher - higher and higher - higher and higher ..." (vol. 4, p. 300). The soaring movement is reminiscent of the father's dream in Heinrich von Ofterdingen, and also recalls the exhilaration that Friedrich and Christlieb feel when they are flying with the Strange Child. The fluidity and expansiveness of Marie's travelling in Toyland is a counterpoint to her daily life, and one way in which she transcends material existence. Furthermore, her passage back and forth between the material and imaginary realms is usually accompanied by uncanny sounds. This tallies with The Golden Pot and The Strange Child, when Anselmus experiences ethereal sounds and music in the portal of Lindhorst's garden and house, and when Felix and Christlieb hear music in the woods just before the Strange Child transports them to fairyland (Note 17). Prosper Alpanus in Little Zaches also travels in a bespangled musical machine, which jangles with wonderful sounds as it moves, and flies on the back 
of a huge humming dragonfly (vol. 3, pp. 587-588, 620). Likewise, mysterious sounds are associated with Drosselmeier's magic. Marie hears "whirring" when she imagines him taking the place of the owl on top of the nursery clock; he sings his "pretty little clockmaking song" for her as she recuperates after cutting her arm (vol. 4, p. 254); and at the close of the tale he is clearly overjoyed that "all my clocks are in order" (vol. 4, p. 306). His sounding clocks are therefore metaphorically associated with access to a transcendent world. His delighted comment on their mechanism demonstrates that events in the real and imaginary worlds have synchronized, enabling the lifting of the curse in both.

To summarize, both The Nutcracker and The Strange Child reveal Hoffmann's respect for child-readers and their ability to understand what might seem to be beyond their years (Note 18). In the discussion about the two tales, Serapion Brother Ottmar makes the point that they are too profound for children, but Brothers Cyprian, Vinzenz and Lothar disagree, implying that Hoffmann endorses a contemporary Romantic validation of the special perceptions of children (vol. 4, p. 615). Together with The Golden Pot, The Nutcracker and The Strange Child feature transcendence involving entry into Secondary Worlds. The enchanted realms of these fairy tales are absorbing and exhilarating for children, poets and child-like adults. Similarly to Bloch, Tolkien maintains that listening to or reading fairy tales amounts to much more than escapism (Tolkien, 2008, p. 74). Rather, their hopeful endings bring consolation and a sense of release in which the reader, like the characters, experiences a "sudden joyous turn ... a fleeting glimpse of Joy, Joy beyond the walls of the world" (ibid, p. 75) (Note 19).

\section{Conclusion}

Hoffmann's literary fairy tales, The Golden Pot, The Strange Child and The Nutcracker conform to the observations of Tolkien that fairy tales comprise permutations of recurring elements in an oral or literary "soup" (Tolkien, 1947, p. 45) (Note 20). This "soup" is made up of old and new "bits, dainty and undainty" (ibid, p. 45). The teller or writer selects from these ingredients, reconstituting the soup to create a "Secondary World" which has its own reality (ibid, p. 52). Imagination empowers listeners or readers to inhabit this enchanted secondary world, Tolkien's realm of "Faerie" (ibid, p. 74), and, on return to their primary world, they "regain ... a clear view"; they experience "recovery [and] renewal"; and they see the materiality around them in a new light (ibid, pp. 67-68). Thus, entry into the realm of "Faerie" surmounts escapism. Our analysis of Hoffmann's literary fairy tales has established that they are, indeed, made up of many old and new elements, all reworked in Hoffmann's individual style, and that they illustrate how flights of the imagination, liberated from narrow rationality, often bring selfknowledge, renewal and a fuller understanding of the material world. Applying Tolkien's concepts to Hoffmann's literary fairy tales also illuminates the importance of his legacy, as the ingredients of Hoffmann's own fairy-tale "soup" find their way into the work of many subsequent writers.

Hoffmann's work did not receive the recognition it deserved in Germany, where, according to O'Sullivan, children's literature was steered "into a blind alley" by the work of the Grimms and later by educationalists (O'Sullivan, 2005, p. 64). With Zipes's confirmation, we are assured that, although they were contemporaries, Hoffmann never encountered the Grimms and was not familiar with their work (Note 21). Instead, Hoffmann's tales quickly crossed the German language barrier, with French translations reaching countries as distant as South America and Russia within twenty years, and an illustrated edition of The Nutcracker was published in New York in 1852. Fantasy fiction using similar ingredients to Hoffmann's "soup" appeared outside Germany in the tales of Hans Christian Anderson, Lewis Carroll, George Macdonald, Edith Nesbit and, later still, Astrid Lindgren (ibid, p. 26). Furthermore, we contend that Hoffmann's tales have also influenced twentieth-century fantasy fiction by C. S. Lewis, Roald Dahl and Philip Pullman. Lewis's familiarity with Hoffmann's "soup" is confirmed by his re-use of the trope of a wardrobe with fur coats from The Nutcracker in The Lion, The Witch and the Wardrobe (1950). Pullman's His Dark Materials (1995) also opens with his heroine, Lyra, hiding in a wardrobe of fur-edged academic robes (Note 22). In Charlie and the Chocolate Factory (1981), Dahl too reworks Hoffmann's scene where the oarsmen of a boat are little boys who row Marie and the Nutcracker-Prince down a lemonade river (Note 23). Such close parallels cannot be accidental. We also propose that Hoffmann's constructs of the Romantic child, the childlike adult, and the philistine adult in his fairy tales reappear in the work of Lewis, Dahl and Pullman. This claim is corroborated and expanded in Gray's recent mythopoeic study, Fantasy, Myth and the Measure of Truth: Tales of Pullman, Lewis, Tolkien, MacDonald and Hoffmann (2008), a critique which "mines the relationship between German Romanticism and British fantasy literature." (Note 24)

\section{Acknowledgement}

We are indebted to several standard works of translation.

\section{References}

Bloch, E. (1988). The Utopian Function of Art and Literature: Selected Essays (1974, J. Zipes and F. 
Mecklenburg Trans.). Cambridge, Massachusetts: MIT Press.

Brown, H. M. (2006). E. T. A. Hoffmann and the Serapiontic Principle: Critique and Creativity. New York: Camden House.

Bruning, P. (1955). E. T. A. Hoffmann and the Philistine. German Quarterly, 28(2), 111-121. https://doi.org/10.2307/401759

Bryson, L. (1999). Romantic Science: Hoffmann's Use of the Natural Sciences in 'Der Goldene Topf'. Monatshefte, 91(2), 241-255.

Buch, D. J. (1992). Fairy-tale Literature and Die Zauberflöte. Acta Musicologia, 64(1), 30-49. https://doi.org/10.2307/932991

Buch, D. J. (2004). Die Zauberflöte, Masonic Opera, and Other Fairy Tales. Acta Musicologia, 76(2), 193-219.

Carpenter, H. (1985). Secret Gardens: A Study of the Golden Age of Literature. Boston: Houghton Mifflin.

Carter, A. (2005). Angela Carter's Book of Fairy Tales. London: Virago.

Cheetham, D. (2006). Charlie and the Chocolate Factory: Versions and Changes. English Literature and Language, 42, 77-96. Retrieved February 26, 2020, from http://academia.edu/1156777/charlie_and_the_chocolate_factory_versions_and_changes

Freud, S. (1991). The Uncanny. In J. S. Freud (Ed. \& Trans.), The Standard Edition of the Complete Psychological Works of Sigmund (Vol. 17, pp. 219-252). London: The Hogarth Press and the Institute of Psycho-Analysis.

Goethe von, J. W. (1977-1980). Wilhelm Meister's Years of Apprenticeship (4 Vols., H. M. Waidson Trans.). London: Calder.

Gray, W. (2008). Fantasy, Myth and the Measure of Truth: Tales of Pullman, Lewis, Tolkien, MacDonald and Hoffmann. London: Palgrave Macmillan.

Hoffmann, E. T. A. (2001). Ernst Theodor Amadeus Hoffmann: Collected Works (Vol. 1, 2003; Vol. 2/1, 1993; Vol. 2/2, 1998; Vol. 3, 1985; Vol. 4, 2001; Vol. 5, 1992; Vol. 6, 2004). Frankfurt: Steinecke, Deutscher Klassiker Verlag.

Kittler, F. A. (1990). Discourse Networks 1800/1900 (1985, M. Metteer Trans.). California: Stanford UP.

Kümmerling-Meibauer, B. (2008). Images of Childhood in Romantic Children's Literature. In G. Gillespie et al. (Eds.), Romantic Prose Fiction (pp. 183-203). Amsterdam: Benjamins. https://doi.org/10.1075/chlel.xxiii.14kum

Lamb, C. (2009). Dream-Children: A Reverie. In The Essays of Elia (1823, pp. 161-165). London: Hesperus.

Neilly, J. (2016). E. T. A. Hoffmann's Orient: Romantic Aesthetics and the German Imagination. Cambridge: Legenda.

Nikolajeva, M. (2003). Fairy Tale and Fantasy: From Archaic to Postmodern. Marvels \& Tales, 17(1), 138-156. https://doi.org/10.1353/mat.2003.0014

Novalis. (1990). Henry Von Ofterdingen (1802, P. Hilty Trans.). Illinois: Waveland Press.

O'Sullivan, E. (2005). Comparative Children's Literature (A. Bell Trans.). Kinderliterarische Komparatistik. London: Routledge.

Oesterle, G. (1991). Arabeske, Shrift und Poesie in E. T. A. Hoffmanns Kunstmärchen, 'Der Goldene Topf'. In Athenäum: Jahrbuch für Romantik (pp. 69-107). Paderborn: Schöningh.

Rousseau, J. (2007). Emile; or On Education (1762). Eastbourne: Gardners Books.

Sahlin, J. C. (1977). Selected Letters of E. T. A. Hoffmann. Chicago: Chicago UP.

Schlegel, F. (1957). Literary Notebooks 1797-1801 (H. Eichner Ed.). London: Athlone.

Schlegel, F. (1967). Charakteristika und Kritiken 1 1796-1801 (H. Eichner Ed.). Munich: Schöningh.

Schubert, G. H. (1808). Ansichten von der Nachtseite der Naturwissenschaften. Dresden: Arnoldsche Buchhandlung.

Scullion, V., \& Treby, M. (2010). Creative Synaesthesia in E. T. A. Hoffmann's Ritter Gluck. European Review, $18(2), 239-262$. 
Tieck, L. (2015). Ludwig Tiecks Schriften (Vol 4. Die Elfen, Phantasus I, 1812, Introduction by A. W. Schlegel). Berlin: Reimer. Retrieved October 9, 2019, from Project Gutenberg eBook \#50480, gutenberg.org/

Tolkien, J. R. R. (2014). On Fairy-Stories. In V. Flieger \& D. A. Anderson (Eds.), Tolkien on Fairy-Stories (1947, pp. 27-79). London: Harper Collins.

Warner, M. (2012). Stranger Magic: Charmed States and the Arabian Nights. London: Harvard University Press. https://doi.org/10.4159/harvard.9780674065079

Willson, A. L. (1964). A Mythical Image: The Ideal of India in German Romanticism. North Carolina: Duke UP.

Zipes, J. (2007). Introduction. E. T. A. Hoffmann: Nutcracker and Mouse King-Alexander Dumas: The Tale of the Nutcracker (J. Neugroschel Trans., p. 12). London: Penguin.

Zipes, J. (2012). Fairy Tales and the Art of Subversion (2nd ed.). London: Routledge. https://doi.org/10.4324/9780203805251

\section{Notes}

Note 1. Hoffmann expresses his debt to the ideas of Schlegel (unclear whether Friedrich or August) and Novalis in diary entries for 12 January and 17 April, 1812, both written during bouts of illness. He describes himself as uplifted (erbaut) by reading them (Hoffmann, 1, pp. 378, 407). The title and contents of his first published piece (1803), which purports to be a letter from a monk to his friend, bear a notable resemblance to Wilhelm Wackenroder's Outpourings of an Art-loving Friar (1797). Ludwig Tieck's introductory poem and the fairy tales in his collection, Phantasus (1799), which includes A Wondrous Oriental Fairy Tale about a Naked Saint and several other posthumous pieces by Wackenroder, creatively influenced Hoffmann's fairy tales. In a letter to Tieck in 1820, Hoffmann describes Phantasus as "magnificent" (Sahlin, 1977, pp. 274, 300).

Note 2. See Sahlin, 1977, pp. 304-305.

Note 3. Hereafter, all references to Hoffmann's Collected Works (1985-2004) are abbreviated to volume and page numbers.

Note 4. All references to Schlegel hereafter refer to Friedrich Schlegel.

Note 5. In Little Zaches, Prosper Alpanus wearing his exotic eastern clothes: "an earthen-yellow Indian gown and little red-laced boots, whether trimmed with coloured leather or the gleaming feather skin of a bird, it was impossible to tell" resembles Lindhorst (Hoffmann, vol. 4, p. 391).

Note 6. Hoffmann's self-consciousness about his handwriting was not purely aesthetic. Since he often lived on the breadline, he was concerned about how many pages of print (and hence his payment), his small, spidery writing would fill (Sahlin, 1977, pp. 198, 295).

Note 7. See Bruning, 1955, pp. 113-115; Bryson, 1999, pp. 246-248.

Note 8. Zipes argues convincingly that the Grimms' fairy tales may appear to come straight from the mouths of storytellers, but are polished imitations of the quality of orality. They were edited by the Grimms to give the impression of a German "folk" essence in order to foster a feeling of Germanic nationhood for a German middle-class readership (Zipes, 2012, p. 58).

Note 9. For "artistic entanglement", see Schlegel, 1967, p. 218, Athenäum Fragmente 311. For "random connectedness of form, see Schlegel, 1967, p. 238, Athenäum Fragmente 389.

Note 10. See Schlegel, 1957, p. 180.

Note 11. The complete sentence reads "(Romantic poetry) can also, more than anything else, hover in the middle between the portrayed and the portrayer, free of all real and ideal self-interest, on the wings of poetic reflection, and can raise that reflection again and again to a higher power, can multiply it in an endless succession of mirrors" (Schlegel, 1967, pp. 182-183, Athenäum Fragmente 116).

Note 12. See Schlegel, 1967, p. 151, Lyceums Fragmente 37.

Note 13. See George Macdonald's The Light Princess (1864); Lewis Carroll's Alice Through the Looking Glass (1871); J. M. Barrie's Peter Pan (1904) and P. L. Travers's Mary Poppins (1934).

Note 14. See diary entry 17 April, 1812 (Hoffmann, vol. 1, p. 407).

Note 15. Freud's The Uncanny (1919) theorizes the uncanny as "something which ought to have remained hidden but has come to light", and "something secretly familiar (heimlich), which has undergone repression, and 
then returned from repression" (unheimlich) (Freud, 1991, pp. 24, 245). He argues that the experience of the uncanny occurs when what is unhomely, secret or thought to be forgotten (unheimlich), erupts into homeliness (heimlich), and so merges with the familiar because it is recognised (ibid, pp. 220-227).

Note 16. Hoffmann lived in Dresden and Leipzig from 1813-1814 during the battles which eventually defeated Napoleon's army. On 8 May, 1813, while watching artillery fire near the Brühl Palace in Dresden, he was hit by a ricocheting bullet which grazed his boot, while other civilians were not so lucky. He comments "I removed myself rather speedily" (Sahlin, 1977, p. 188).

Note 17. For analysis of integral connections between music and writing in Hoffmann's work, see Val Scullion \& Marion Treby, 2010, pp. 243-244.

Note 18. In a letter to his friend, Theodor Hippel, Hoffmann writes "your children must read [The Golden Pot] too, even the younger ones, for I have found that, although children cannot possibly understand the deeper meaning yet, many scenes have considerably aroused their fantasy." (Sahlin, 1977, p. 246). The Nutcracker and the Mouse King and The Strange Child were originally written for the children of his friend, Julius Hitzig. Concerning republishing them in The Serapion Brothers collection, Hoffmann writes in a letter to him, "Das Fremde Kind ... is purer, more childlike, and therefore more suitable for children, even if they do not understand the deeper meaning of the whole." (ibid, p. 276).

Note 19. Tolkien coins the word "Eucatastrophe" to describe this elevated, visionary state of mind (Tolkien, 2008, p. 74).

Note 20. Angela Carter, acclaimed writer and editor of feminist fairy tales, makes a similar point using the trope of "soup". See Carter, 2005, pp. 12-13.

Note 21. We are indebted to Zipes for confirming this fact. Personal email: 21 July, 2016.

Note 22. The scene with the wardrobe and fur-lined academic robes may be accounted for by Pullman writing against C. S. Lewis, rather than Pullman borrowing directly from Hoffmann.

Note 23. Roald Dahl follows Hoffmann's river journey scene so closely that even his boy rowers are dark-skinned in the first edition of Charlie and the Chocolate Factory. As the result of political pressure, which accused him of racism, he changed them to the fantastical Oompa-Loompas, see Cheetham, 2006, pp. 77-96.

Note 24. This endorsement on the back cover of William Gray's Fantasy, Myth and the Measure of Truth (2008) comes from Donald Haase, authority on fairy tales and former editor of Marvels and Tales.

\section{Copyrights}

Copyright for this article is retained by the author, with first publication rights granted to the journal.

This is an open-access article distributed under the terms and conditions of the Creative Commons Attribution license (http://creativecommons.org/licenses/by/4.0/). 